\title{
Thomas Middleton
}

\section{$1580-1627$}

Thomas Middleton was born in London, the son of a prosperous bricklayer. He was educated at Queen's College, Oxford, but left without a degree. By 1600 he had moved to London and was associated with the theatres. During the next twenty years he wrote a large number of plays (often in collaboration with others), pageants and masques. His best-known plays are The Roaring Girl (written with Thomas Dekker), A Fair Quarrel, and A Chaste Maid in Cheapside (written with William Rowley). 'Midnight's bell' is a song in his play Blurt, Master Constable.

\section{From BLURT, MASTER CONSTABLE}

\section{Midnight's bell}

Midnight's bell goes ting, ting, ting, ting, ting,

Then dogs do howl, and not a bird does sing

But the nightingale, and she cries twit, twit, twit.

Owls then on every bough do sit,

5 Ravens croak on chimney's tops,

The cricket in the chamber hops,

And the cats cry mew, mew, mew.

The nibbling mouse is not asleep,

But he goes peep, peep, peep, peep, peep,

And the cats cry mew, mew, mew,

And still the cats cry mew, mew, mew. 